\title{
The Impacts, Benefits and Cost of Sustainable Renovation to Existing Buildings in Mauritius and Setting up of Possible Strategies-Two Case Studies
}

\author{
Reshma Rughooputh (Corresponding author) \\ Civil Engineering Department, Faculty of Engineering \\ University of Mauritius, Reduit, Mauritius
}

Tel: 230-403-7850 E-mail: reshma@uom.ac.mu

Jayrani Cheeneebash

Department of Mathematics, Faculty of Science

University of Mauritius, Reduit, Mauritius

Tel: 230-403-7496Ｅ-mail: jayrani@uom.ac.mu

Muhammad Irfaan Mungroo

Civil Engineering Department, Faculty of Engineering

University of Mauritius, Reduit, Mauritius

Tel: 230-5918-6604 E-mail: muhammad.mungroo@umail.uom.ac.mu

Received: August 5, 2014 Accepted: August 19, 2014

doi:10.5296/emsd.v3i2.6357 URL: http://dx.doi.org/10.5296/emsd.v3i2.6357

\begin{abstract}
The construction industry remains the least sustainable area and largely involves the use of non-renewable resources. More importantly, the largest source of green-house gas emissions, emanate from conventional (non-green) buildings and the transport sector; contributing enormously to climate change. Although the importance of protecting the environment for future generation has been recognised by all major polluting countries of the world, many countries refuse to comply with all the conditions of environmental protocols because of the economic implications.
\end{abstract}




\section{Ml Macrothink}

Environmental Management and Sustainable Development

ISSN 2164-7682 2014, Vol. 3, No. 2

The aim of this paper is to determine the barriers different implications of sustainable renovation to existing residential buildings and mixed development (complex consisting of residential apartments, commercial spaces and offices) in Mauritius. This work has also as objective to propose measures to make these existing buildings greener, that is efficient in energy use, water consumption and solid wastes generation, less pollution and improved air qualities.

Two case studies were chosen to widen the scope of sustainable renovation and surveys were carried out to gather as much information as possible on the buildings, such as site interface, building architecture, energy and water use, building materials used and waste management. From the analysis, different proposals in conformity with specific green building codes were made.

A cost benefit analysis was carried out for a study period of 25 years and the Net Present Value (NPV) calculated was- 92 018.26 MUR (Mauritian Rupees). The calculated NPV is negative indicating that a deficit was made and the investments made will not be recouped after 25 years.

Although applying green building codes may be costly initially, the foreseen future is optimistic as different technologies will be more accessible. There are various inexpensive measures and techniques that can be adopted to save energy and water, reduce pollution and protect the environment.

Keywords: Sustainable building, Non-renewable resources, Sustainable renovation, Green building codes, Net Present Value

\section{Introduction}

Estimated to be worth 10\% of global GDP (US\$7.5 trillion) and employing 111 million people, the building sector is also the single largest contributor to global GHG emissions. Approximately 60 per cent of the world's electricity is consumed by residential and commercial buildings. In Mauritius, the construction sector accounted for 3.5\% of the gross domestic product (GDP) in 2012 (Stockbroking, 2012).

Existing buildings represent significant energy saving opportunities because their performance level is frequently far below current efficiency potentials. In developing countries, new green construction yields enormous opportunities. Population growth, prosperity and increasing urbanization fuel building and construction activities and this represent up to $40 \%$ of GDP. Investment in building energy efficiency is accompanied by significant direct and indirect savings, which help offset incremental costs, providing a short return on investment period (UNEP, 2011).

An increasing population coupled with multiple economic activities, including tourism have given rise to a net increase of $16.1 \%$ in the number of buildings from 268,300 in 2000 to 311,500 in 2011 (CSO, 2011). The demand for buildings still represents the largest single pressure on the future use of land in Mauritius owing to the limited land available. This is one of the main reasons for a shift in interest from new construction to renovation. Over 3000 
building permits are issued yearly for renovation purposes (CSO, 2011). Moreover, existing buildings need to be maintained, repaired, renovated and sometimes restructured to serve new functions.

A sustainable building focuses on increasing the efficiency of resource use, while reducing building impact on human health and the environment during the building's lifecycle through better design, construction, operation and maintenance (Mauritius Research Council, 2012). The United States Green Building Council (USGBC) views sustainable renovation as any kind of upgrade at an existing building, that is wholly or partially occupied, to improve energy and environmental performance, reduce water use, and improve the comfort and quality of the space in terms of natural light, air quality, and noise, all done in a way that it is financially beneficial to the owner. Sustainable buildings offer many benefits that conventional buildings do not, among which are the following:

\section{i) Environmental benefits}

- Enhancement and protection of biodiversity and ecosystems

- Improvement of air and water quality

- Reduction of waste streams

- Conservation and restoration of natural resources

ii) Economic benefits

- Reduction of operating costs

- Enhancement of asset value, services and profits

- Improvement of occupant productivity and satisfaction

- Optimisation of life-cycle economic performance

iii) Social benefits

- Enhancement of occupant comfort and health

- Improvement of air, thermal and acoustic environments

- Minimisation of strain on local infrastructure

- Improvement of overall quality of life

Despite all the benefits they offer, sustainable practices in the construction industry are being adopted at a very slow pace in Mauritius. The following barriers have been identified:

- Lack of a shared vision on sustainable buildings for Mauritius.

- Lack of clear definition of what green buildings relate to.

- Procurement process does not take into consideration the criteria for sustainable buildings.

- Appraisal/permitting process does not give credit to sustainable buildings.

- Absence of building codes and incentives to promote sustainable buildings.

- Existing Building Act does not set the standard for sustainable buildings.

- Sustainable factor is not a priority in the building design and construction industry.

- Lack of proper enforcement of guidelines and legislation.

- Lack of public awareness and lack of client demand - residential buildings (one storey high mainly) designed without architects.

- Cultural resistance to change in the way buildings are done. 


\section{Ml Macrothink}

Environmental Management and Sustainable Development

ISSN 2164-7682

2014, Vol. 3, No. 2

To examine and assess the environmental performance of a building, sustainable building rating systems are used. These are tools which consist of guidelines and the implementation of these guidelines are assessed and given a score.

Currently in Mauritius, no such rating system or guidelines exist to assess the performance of buildings. Hence, international rating systems such as Leadership in Energy and Environmental Design (LEED), Building Research Establishment Environmental Assessment Method (BREEAM) and Eco Housing Assessment Criteria (IIEC) have been reviewed in this paper.

The issues to be considered in a sustainable building are usually grouped in the following seven categories (IIEC, 2012):

1) Building Information \& Site Planning ( Landscaping, biodiversity, green space, drainage systems)

2) Environmental Architecture (Maximum ventilation and daylight use, indoor environment quality)

3) Energy Conservation and Management (Energy efficiency, Renewable sources)

4) Efficient Building Materials ( Renewable source, recycled, obtained locally)

5) Water Conservation ( Efficient water management, rain water harvesting, grey water treatment)

6) Solid Waste Management ( Segregated bins, composting)

7) Other Measures (Pest control, handicapped facilities)

The potential reductions which could be achieved through changes in the planning, construction and operation of buildings are estimated below (Boyle, 2005).

\begin{tabular}{|c|c|}
\hline ACTIVITY & POTENTIAL REDUCTION \\
\hline \multicolumn{2}{|c|}{ Planning } \\
\hline Increasing urban density & $\begin{array}{c}\text { Improvement in building value } \\
\text { of erosion }\end{array}$ \\
\hline Development of marginal lands & $\begin{array}{c}\text { 40-50\% improvement in crop production; reduction } \\
\text { Integrated urban and architectural design }\end{array}$ \\
\hline Incorporation of green and open space & $90 \%$ energy; improvement in human health \\
\hline Human-powered transportation & 50\% in energy and impacts \\
\hline Establishment of mixed-growth managed forest to \\
supply industries
\end{tabular}




\begin{tabular}{|c|c|}
\hline Water tanks, composting toilets & $80-90 \%$ external water and energy \\
\hline \multicolumn{2}{|c|}{ Operation } \\
\hline Low energy, low water appliances & $20-50 \%$ energy and water \\
\hline Use of human-powered transportation & $90 \%$ energy; improvement in health \\
\hline Minimising water and energy use & $10-20 \%$ energy and water \\
\hline Maintaining and refurbishing buildings & $50-80 \%$ over 200 years \\
\hline
\end{tabular}

\section{Methodology}

In order to investigate the environmental impacts of buildings in Mauritius, the following methodology was evolved:

i. A comparative study of international sustainable rating systems was carried out. Guidelines from LEED, BREEAM and IIEC were analysed and those which could be applied in the local context were selected for implementation.

ii. Since guidelines for residential houses, commercials and offices are almost the same with a few exceptions, a single comparative study was carried out among the 3 above mentioned rating systems and whenever was the case, specific codes were mentioned for any particular type of buildings.

iii. Two case studies were selected, namely a residential building and a mixed development (residential plus commercial). The 2011 Housing Census counted 311,500 buildings in the Republic of Mauritius with a majority $(264,100$ or $84.8 \%)$ of residential buildings. (CSO, 2011) Residential building is the most common building in the country; hence, a residential building was deemed best as case study. It is hoped that setting up of guidelines for sustainable renovation of domestic houses will be of great help for the population in the future. The mixed development is another type of building which is gaining popularity nowadays in Mauritius. These types of buildings usually comprise offices, commercials and residential apartments and have shown an increase of about $10 \%$ in the last decade (CSO, 2011). Carrying out a research on a mixed development provides the challenge of studying both the residential and commercial aspect of a building.

iv. Data was collected through site visits and surveys. A questionnaire was designed in relevance to sustainable renovation and the different owners were interviewed.

v. A cost analysis was carried out to investigate how profitable key proposed recommendations would be.

vi. Finally, a set of guidelines was developed for sustainable renovation purposes in Mauritius.

\section{Results and discussions}

The information recorded for both case studies were grouped in seven categories. The focused aspects of each category are as listed below.

\begin{tabular}{|c|c|}
\hline \multicolumn{2}{|c|}{ Building Information \& Site Planning } \\
\hline Focused aspects & Site area, building footprint, Landscaping, Adjacent structures, Drainage \\
\hline Environmental Architecture \\
\hline
\end{tabular}




\begin{tabular}{|l|c|}
\hline Focused aspects & Orientation of buildings, Openings, leaks, Flooring, Paints \\
\hline \multicolumn{2}{|c|}{ Energy Conservation and Management } \\
\hline Focused aspects & Lighting units, Energy sources, Ventilation, Renewable sources \\
\hline \multicolumn{2}{|c|}{ Efficient Building Materials } \\
\hline Focused aspects & Structures materials, paints, CFC, openings, flooring, furniture \\
\hline \multicolumn{2}{|c|}{ Water Conservation } \\
\hline Focused aspects & Pipe material, fittings, toilet flush, rainwater harvesting, grey water treatment \\
\hline Focused aspects & Solid Waste Management \\
\hline \multicolumn{3}{|c|}{ Types of bins, composting, removal of recycled wastes } \\
\hline Focused aspects & Pest control, protection of water bodies, handicapped facilities \\
\hline
\end{tabular}

\subsection{Case Study 1: Residential building}

The collected data were analysed and recommendations were put forward. The proposed changes that could be achieved in the local context are listed below, in their respective categories.

\section{1) Building Information \& Site Planning}

i. Landscaping must be planned properly and trees need to be planted at strategic positions on the east and west sides of the building to maximise their use as wind breakers and provision of shade.

ii. Drainage system must be designed for storm water run-off to prevent accumulation of water during heavy rainfall.

iii. Gravelled landscaping should be encouraged as it has good absorption capacity and hence, good for recharge of water table.

\section{2) Building Architecture \& Performance}

i. It is proposed to replace the old windows with double glazed ones which help to reduce heat build-up during hot weather and heat loss during winter.

ii. For bathrooms and toilets, ceramic tiles remain the ideal type of flooring due to easy maintenance and long duration while for the other rooms; the proposed solution is bamboo flooring. The latter is eco-friendly flooring, has a lifetime of 30-50 years, and is water resistant and anti-microbial.

iii. It is advised to make use of natural plant or mineral-based finishes and adhesives are available from a number of sources.

iv. It is recommended to provide roof insulation to heat built-up in a building during summer and heat loss during winter.

\section{3) Energy Conservation and Management}

i. The first recommendation is to replace all incandescent bulbs by CFLs as the latter are more energy efficient and consume less electricity.

ii. It is also proposed to replace all the electrical wires to prevent excessive electricity consumption and for safety reasons since their lifetime of 20 years have been exceeded.

iii. Depending on the amount of light needed, dimmable switches can be used whenever possible. Other energy efficient techniques like the use of timers or sensors for other electrical appliances may be used. 
iv. Stand fans are used in all four bedrooms and the living rooms for ventilation but they are ineffective if there is no air flow. The proposed solution is the use ceiling fans for better airflow.

v. For water heating system, the solar water heater, being a renewable form of energy, would be more appropriate.

\section{4) Efficient Building Materials}

i. It is advised to make as much use as possible of recycled materials for construction and renovation purposes; for example, the use of rock sand.

ii. Any material needed during renovation or construction should be obtained locally and within a reasonable distance from the site.

iii. Heating up of concrete building remains a major problem and right now, the best way to reduce heat absorption is to provide natural shade around the building by planting natural trees or by means of artificial shade.

iv. There are a number of furnishings which are made of wood in the house and hence, it is very important that they are cleaned regularly to remove dust and bacteria. Damaged/ worn up wooden elements need to be replaced, it is highly recommended to use certified wood wherever applicable.

v. Some furniture are also made of metals and hence, when using paint or any other cleaning agents, it is advisable to use eco-friendly paints or cleaning agents and water-based solvents made from natural sources and free from hazardous chemicals.

vi. For bathrooms and toilets, ceramic tiles remain the ideal type of flooring due to easy maintenance and long duration. For the other rooms, the proposed solution is bamboo flooring.

\section{5) Water Conservation}

i. All the taps are normal taps and proposition was made to replace them with water efficient taps with aerators, sensors or those designed by flow rates.

ii. It was advised to replace the PVC pipes by High Density Polyethylene (HDPE) pipes which have demonstrated its effectiveness through its durability, leak-free performance, corrosion resistance, and ductility. Its greater resilience and flexibility make it less susceptible than PVC to surges, damage from digging, and shifting soils during earthquakes. HDPE is also preferable to PVC as it is chlorine-free, requires fewer additives in its manufacture, and has a much higher recycling rate than PVC (MRI Water Solutions, 2013).

iii. One recommendation would be to use low flush toilets of capacity 6L. Another improvement can be the use of dual flush toilet with a flow rate of $3 \mathrm{~L}$ and $6 \mathrm{~L}$ per flush so that the user can decide the amount of water he needs. Excess space inside the toilet tank can be filled (use of a light weight brick) to ensure less water is used. Old water bottles filled with rocks (to weigh it down) can also be used for this purpose.

iv. It is suggested to set up rain water harvesting system to meet the water demand of the house especially for toilet, and gardening use.

6) Solid waste management

i.Proposition is made to replace the main central bin by a segregated bin whereby solid wastes will be separated according to their types.

ii.A space must be set up for the composting of food and kitchen wastes to be used as manure and hence, reducing the amount of wastes sent to landfills.

iii.It is important to establish a contract with local dealers for the collection of recycled solid wastes like used glass bottles or used metals structures. 
7) Other measures

i. Facilities should be provided for handicapped persons in terms of easy access and comfort in the house as this has been adopted in the sustainable building guidelines.

ii. Request should be made to the Ministry of Health to send Health officers for vector checks on a regular basis.

\subsection{Case Study 2: Mixed development}

The proposed changes that could be achieved in the local context are listed below, highlighted in their respective categories.

\section{1) Building Information \& Site Planning}

i. Landscaping must be planned properly. Trees need to be planted wherever possible and at strategic positions to maximise their use as wind breakers and provision of shade.

ii. Green spaces other than trees must be set up to provide biodiversity.

2) Building Architecture \& Performance

i. New openings or increase in the size of current openings in cases where new openings cannot be added need to be catered for. These will ensure better air circulation, proper ventilation and maximum use of daylight.

ii. All windows, especially on the west side, must be double glazing to provide heat insulation and hence, help to keep the indoor environment comfortable.

iii. Roof insulation to reduce heat gain during hot season and heat loss during winter need to be considered.

iv. Provide stairs, balconies and verandas will provide better air circulation and good ventilation and the users will be more comfortable with the indoor atmosphere (for residential).

v. Set up a home office to allow user to work from home at ease (for residential).

vi. Provision of a roof garden to reduce the heating up of the roof and hence, enjoying a more comfortable indoor atmosphere must be encouraged.

vii. Office and commercial owners should make it a must to provide bicycle storage and changing rooms to their employees so as to reduce the dependency on carbon-based fuels and gradually attain the goal of zero carbon.

\section{3) Energy Conservation and Management}

i. The first proposal was to replace all incandescent bulbs by CFLs as the latter consume less electricity, have a higher lifetime and are more efficient.

ii. It is recommended to replace all the wires to reduce electricity consumption and for safety reasons since their lifetime of 20 years have been exceeded.

iii. The proposed solution for the stand fan in the apartments is the use ceiling fans for better airflow.

iv. Depending on the amount of energy (light \& ventilation) needed, efficient energy saving techniques like the use of timers, dimmable switches or sensors may be used.

v. Energy saving techniques must be applied when using the air conditioning unit since the latter consumes a lot of electricity.

vi. Renewable sources of energy other than the solar water heater must be explored like the use of photovoltaic outdoor lighting which can be applied for parking lighting. 


\section{Macrothink}

vii. People should also be encouraged to use certified luminaries and appliances as they are of better quality and of longer duration and the user benefits financially on the long run.

4) Efficient Building Materials

i. It is advised to make as much use as possible of recycled materials for construction and renovation purposes.

ii. Any material needed during renovation or construction should be obtained locally and within a reasonable distance from the site.

iii. Heating up of concrete building remains a major problem, the best way to reduce heat absorption is to provide natural shade around the building by planting natural trees or by means of artificial shade.

iv. There are a number of furnishings which are made of wood in the house and hence, it is very important that they are cleaned regularly to remove dust and bacteria. Damaged/ worn up wooden elements need to be replaced, it is highly recommended to use certified wood wherever applicable.

v. Some furniture are also made of metals and hence, when using paint or any other cleaning agents, it is advisable to use eco-friendly paints or cleaning agents and water-based solvents made from natural sources and free from hazardous chemicals.

vi. For bathrooms and toilets, ceramic tiles remain the ideal type of flooring due to easy maintenance and long duration. For the other rooms, the proposed solution is bamboo flooring.

\section{5) Water Conservation}

i. All the taps and fittings are of normal types and it is suggested to replace them with water efficient taps with aerators, sensors or those designed by flow rates.

ii. It is advisable to replace the PVC pipes by High Density Polyethylene (HDPE) pipes which have been proved to be better than PVC and less hazardous.

iii. It is also important to carry out regular check for leaks to prevent loss of water.

v. All the toilets have single flush of 9L capacity. One recommendation would be to use low flush toilets of capacity 6L. Another improvement can be the use of dual flush toilet with a flow rate of $3 \mathrm{~L}$ and $6 \mathrm{~L}$ per flush so that the user can decide the amount of water he needs. Excess space inside the toilet tank can be filled (use of a light weight brick) to ensure less water is used. Old water bottles filled with rocks (to weigh it down) can also be used for this purpose.

iv. It is suggested to set up a rain water harvesting system to satisfy the water demand of the complex especially for toilet, washing and gardening use.

v. Currently, there is no absorption pit or septic tank for the storage of waste water and the latter is directed to rain water drainage system. This often causes bad smell of drains and during heavy rainfall, drains are overflowed very easily. Hence, absorption pit or septic tank must be provided for waste water

vi. It is also important to carry out regular check for leaks to prevent loss of water. Leakage of water can be detected in the following manner:

a) Close all outlet taps, except the stop-cock near the meter. 
b) Observe the meter dial to see if the meter is registering consumption. If such is the case, then there must be a leak somewhere along the supply pipe. (CWA, 2013)

vi. One recommendation would be to use low flush toilets of capacity 6L. Another improvement can be the use of dual flush toilet with a flow rate of $3 \mathrm{~L}$ and $6 \mathrm{~L}$ per flush so that the user can decide the amount of water he needs. Excess space inside the toilet tank can be filled (use of a light weight brick) to ensure less water is used. Old water bottles filled with rocks (to weigh it down) can also be used for this purpose.

vii. It is suggested to set up a rain water harvesting system to meet the water demand of the house especially for toilet and gardening use.

6) Solid waste management

i. Proposition was made to replace the main central bin by a segregated bin whereby solid wastes will be separated according to their types.

ii. A space must be set up for the composting of food and kitchen wastes to be used as manure and hence, reducing the amount of wastes sent to landfills.

iii. It is advised to establish a contract with local dealers for the collection of recycled solid wastes like used glass bottles or used metals structures.

7) Other measures

i. Facilities should be provided for handicapped persons in terms of easy access and comfort in the house as this has been adopted in the sustainable building guidelines.

ii. Request should be made to the Ministry of Health to send Health officers for vector checks on a regular basis.

\subsection{Cost Benefit Analysis}

Following the survey, possible recommendations were made to make both buildings conform to green building codes. The implementation of the possible recommendations were analysed financially only for the first case study and the results were compared for the second case study.

Main changes brought about:

1. Replacing electric water heater with solar water heater

2. Replacing incandescent bulbs and tube lights by Compact Fluorescent Lamps (CFLs)

3. Installing aluminum foil for roof insulation.

4. Providing double glazed windows and doors on the west side of the building.

5. Setting up of a rain water harvesting system

6. Adopting the dual toilet flush system

7. Replacing conventional taps / fixtures with ones equipped with aerators

\begin{tabular}{|c|c|c|c|}
\hline Recommendations & Investments / MUR & Annual savings/ MUR & Payback period*/ Yrs \\
\hline Solar water heater & 20,475 & 3675 & 5.6 \\
\hline
\end{tabular}




\begin{tabular}{|c|c|c|c|}
\hline Luminaries & 1210 & 930.41 & 1.3 \\
\hline Aluminium roof insulation & 11000 & & \\
\hline Double glazing & 87,106 & & \\
\hline Rainwater harvesting system & 27,500 & 834.96 & 33 \\
\hline Water fixtures & 3150 & 344.16 & 9.2 \\
\hline Dual toilet flush tanks & 1600 & 326.16 & 4.9 \\
\hline TOTAL & 152041 & 6110.69 & \\
\hline
\end{tabular}

*Payback period: Number of years after which investments are recouped.

\subsection{Net Present Value (NPV)}

Money which occurs at different points in time cannot be compared directly but must first be converted to a common point of time, which is the present time. This process is called discounting and a discount rate is used to discount all the future cash flows back to the present. The net present value is calculated to determine whether the proposed investments will be profitable on the long term. A positive NPV indicates that the project has a higher return than that on other similar risk level investments, that is, the project is more profitable.

In this particular case, the NPV will be calculated for a period of 25 years as this is the maximum lifetime of the solar water heater.

The discount rate used is $9.0 \%$ (IndexMundi, 2013 )

The Net Present Value is given by:

Net present value $=-$ investment + annual savings $\frac{(1+i)^{n}-1}{i(1+i)^{n}}$

$$
=-152041+6110.69 \frac{(1.09)^{25}-1}{0.09(1.09)^{25}}
$$

$$
\text { NPV }=-\underline{92018.26} \text { MUR }
$$

The calculated NPV is negative indicating that the proposed changes will not be profitable. A deficit was made and the investments made will not be recouped after 25 years. This is because the changes made are too consequent and the savings made are too small to recover the investment cost.

Profit can only be made if smaller investments are made since it is difficult to generate more profits. Recommendations like solar water heaters, CFLs, efficient taps with aerators and 


\section{Macrothink}

dual toilet flushes can be followed as important sustainable solutions. Likewise, an increase in discount value may also increase the Net Present Value and make the investments more profitable.

\section{Guidelines for Sustainable Buildings}

Based on the comparative study carried out among the Eco Housing Assessment Criteria of IIEC, Leadership in Energy and Environmental Design (LEED) and Building Research Establishment Environmental Assessment Method (BREEAM) together with local authorities like the Central Water Authority (CWA) and Central Electricity Board (CEB), a set of criteria was identified for a building to qualify for minimum sustainability which could be applicable in the Mauritian context.

As shown in the comparative study, international rating systems have more or less the same guidelines for a residential house, a commercial building and an office. Since a mixed development contains all three types of buildings, a common set of criteria was established.

It is also vital to establish institutional frameworks and professionals to regulate and enforce the assessment process. The developed guidelines are listed in each of the seven categories of sustainability.

\subsection{Site Planning}

\section{INTENT:}

To protect environmentally sensitive areas and ecologically valuable sites from disturbance during and after construction; to preserve biodiversity and ecosystems; to improve thermal comfort; to facilitate ground water recharge and to reduce dependency on fossil fuels-based vehicles.

\section{Mandatory measures:}

- Landscaping must be done on the east and west side of the building.

- Existing vegetation must be preserved on site.

- Avoid building on sites of ecologic value like areas serving as habitat for endangered plant and animal species or having a fragile ecosystem.

\section{Voluntary measures:}

$>$ Provide shade on non-roof surfaces like parking lots, walkways, plazas.

$>$ Provide a place for bicycle storage to encourage user to use bicycles.

$>$ Provide changing rooms for users (for commercial and office buildings).

\subsection{Environmental Architecture}

\section{INTENT:}

To improve quality of life through good day-lighting, efficient ventilation, thermal and visual comfort while also reducing the use of artificial lighting, ventilation and air-conditioning or heating equipment. 


\section{Mandatory measures:}

- Proper orientation of the building must be done by an architect for renovation works.

- Appropriate overhang must be designed and sized for all openings to prevent any undesired sunlight.

- Total area of openings (inlet and outlet) should be a minimum of $30 \%$ of floor area.

- Provide buffer spaces (staircases, lifts, store, toilets) on $30-50 \%$ of west wall of building

- Use trees and plantings to reduce summer solar gains, to channel summer breezes, and to block winter winds.

\section{Voluntary measures:}

$>$ Provide roof gardens

$>$ Avoid smoking indoors and provide smoking zones (For commercial buildings and offices)

$>$ Be space efficient by build the least area suiting the needs of the house that requires the least energy to maintain; e.g. combined uses.

$>$ Put a large floor mat at every door as people track in all sorts of chemicals via the dirt on their shoes.

$>$ Keep pets outdoors as often as possible or deep clean areas where pets are permitted and give the pets regular bath.

\subsection{Energy Conservation and Management}

\section{INTENT:}

To make efficient use of energy within the building to reduce electricity consumption, dependency on fossil fuels and thus greenhouse gas emissions.

\section{Mandatory measures:}

- Electrical circuits must be designed by electrical engineer

- Lighting power density to be restricted to $7.5 \mathrm{~W} / \mathrm{m}^{2}$.

- Efficient luminaries and appliances must be used.

- Solar water heating system must be provided.

- Air conditioning Unit must not exceed rating of 9000 British Thermal Unit (B.T.U.)

\section{Voluntary measures:}

$>$ Certified luminaries and appliances must be used.

$>$ Photo voltaic system should be provided to meet the electricity demand of the building.

$>$ Make use of energy efficient switches like dimmers, timers and sensors.

$>$ Switch off the light when leaving the room and provide two-way switches for stairs and corridors.

$>$ Favour the use of table lamps for a specific task instead of a large central lighting.

$>$ Open the door of the refrigerator only when necessary and close it as soon as possible.

$>$ Always set the air conditioning $5^{0} \mathrm{C}$ below the external temperature.

$>$ Close all doors, windows, wardrobes and cupboards while using the air conditioning, else much energy will be lost in cooling unnecessary places. 
$>$ Verify and clean the filters of the air conditioning regularly. A dirty filter may cause an over consumption of $5 \%$ of electricity.

$>$ Use vapour iron machines as they smooth out clothes more easily.

$>$ When using cooking oven, make sure the door remains closed as each time the door is opened, there is a temperature loss of $20^{\circ} \mathrm{C}$. (CEB, 2006)

\subsection{Efficient Building Materials}

\section{INTENT:}

To improve thermal comfort by minimising heat gain of the building; Lower resources depletion, skip pollution caused during extraction and processing of materials and reduce load on landfills by using recycled materials and also recycling materials.

\section{Mandatory measures:}

- Exterior walls must be $200 \mathrm{~mm}$ thick.

- Windows and doors must be double glazing.

- Appropriate roof insulation must be done to minimise heat gain.

- Certified wood should be used for construction or as building material.

- Use MDF or Mica laminates instead of plywood.

\section{Voluntary measures:}

$>$ Durable and low-maintenance materials must be use to minimise replacement intervals and maintenance requirement.

$>$ Materials with low embodied energy should be used.

$>$ For water proofing chemicals, additives, sealants and adhesives, use of water based chemicals instead of solvent based for $100 \%$ of use.

$>$ Provide bamboo flooring.

$>$ Use Cement paint, Epoxy resin paint as external paints.

$>$ Use Water based paints, enamels, primers and polishes as internal paints.

$>$ Use building materials obtained locally.

$>$ Stop the use of CFCs products.

\subsection{Water Conservation}

\section{INTENT:}

To promote water efficiency within the building to reduce load on existing systems and preserve the available water resources; provide quality water to users

\section{Mandatory measures:}

- Plumbing system must be designed by mechanical engineer.

- All WC to be used with dual flush system with a flow rate of $3 \mathrm{~L}$ and $6 \mathrm{~L}$ per flush.

- All faucets and fixtures should be low flow to maintain flow rates not exceeding 8 litres per minute and with aerators. 
- Rain water must be harvested, stored/recharged and provisions must be made for utilization for gardening and flushing in WC.

- Water tank must be provided for storage of water.

- Regular checks on plumbing lines

\section{Voluntary measures:}

Plumbing lines must be separated for each floor.

$>$ A treatment system based on non-energy intensive and eco friendly technology should be installed for treatment of total volume of grey water.

$>$ Washing machines which are energy and water efficient should be used.

$>$ Dual plumbing lines should be provided to separate grey water and black water

Avoid unnecessary toilet flushing.

$>$ Do not let water run while brushing the teeth or washing the face.

$>$ Run washing machine and dish washer only when they are full.

\subsection{Solid Waste Management}

\section{INTENT:}

To reduce waste generation to reduce load on landfills and treatment plants.

\section{Mandatory measures:}

- Segregated bins/chutes for every block / building must be provided for collection and separation of $100 \%$ of bio-degradable, non-biodegradable and recyclable wastes.

- A central space for storage of wastes must be set up.

\section{Voluntary measures:}

$>50 \%$ of construction waste should be diverted from landfills through recycling and salvaging.

$>$ Contracts should be made with local dealers for collection and transportation of recyclable solid wastes

$>$ A decentralized onsite treatment plant based on non energy intensive and eco-friendly technology should be set up to treat $100 \%$ organic wastes.

\subsection{Other Measures}

\section{INTENT:}

To adapt efficient and scientific approaches to any other aspect in a building

\section{Mandatory measures:}

- Construction safety measures must be adopted.

- Facilities for handicap access should be provided. (Commercial and office buildings)

\section{Voluntary measures:}

Measures should be adopted to control levels of suspended particulate matter. 
$>$ Sound insulation should be provided to protect against sound pollution and to reduce the likelihood of noise complaint.

$>$ Water bodies should be well covered to prevent mosquito proliferation.

\section{Conclusion}

The aim of this paper was to apply sustainable building concepts to existing buildings in Mauritius, analyse its barriers and cost implication. This research work has also as objective to set up possible strategies for future use and at the same time raise awareness among people that green renovation is a financially beneficial investment in Mauritius. The main conclusions of this study are as follows:

- The demand for buildings still represents the largest single pressure on the future use of land in Mauritius. Owing to limited amount of land in Mauritius, there has been a shift in interest from new construction to renovation as can be seen from the CSO report 2011, over 3000 building permits are issues yearly for renovation purposes (CSO, 2011).

- In order to qualify a building as sustainable some minimum criteria as well as voluntary measures were identified. The measures were grouped in the following categories: site planning, environmental architecture, energy efficiency, water conservation, efficient building materials, solid waste management and other measures.

- A comparative study among international rating systems was carried out as there are currently no sustainable building codes in Mauritius. The three international rating systems that were chosen were the Eco Housing Assessment Criteria of IIEC, Leadership in Energy and Environmental Design (LEED) and Building Research Establishment Environmental Assessment Method (BREEAM) due to their good performance in their respective countries and ease of getting information from their websites.

- Two case studies were selected and data was collected in accordance to the seven categories of building sustainability. Two different types of building were chosen; namely a residential building and a mixed development. As much information as possible was collected in both case studies and the information gathered was analysed. One of the main observations is that Mauritians are reluctant to take the next step from tradition building methods to sustainable techniques.

- From the cost analysis carried out, it was clear that the implementation of sustainable building practices is costly as large investments are required. Bringing changes to an existing structure cost a lot of money as the building may not have been properly built. It is therefore very important that owners of new buildings plan very carefully the construction of their building.

- Despite the monetary and non-monetary benefits that a sustainable building offers, it is being adopted at a very slow pace in Mauritius. Lack of public awareness is one of the major barriers. Long term thinking approach and environmental benefits which are the foundation of sustainable building practices is not being adopted. 


\section{Macrothink}

- Workshops have to be organised by green building developers to educate people about the benefits of sustainable buildings and warn them against both the short term and the long term dangers of conventional buildings.

- Besides the solar water heater, the government should also provide grants for photovoltaic panels and taxes should be exempted from CFLs, efficient water fixtures, dual flush toilet and materials used for double glazed windows/doors.

- To reflect the cost analysis for the described case studies, an in depth empirical research focusing on an econometric estimation to analyse the problem needs to be carried out as future work.

The planet's resources are being depleted at a very alarming rate and if proper steps are not taken, we might be facing a consequential crisis in the future. This is why it is vital to start acting in a conscious and responsible manner, starting with the efficient use of natural resources. The public must be made aware that sustainable buildings aim at reducing the negative impacts on the environment through efficient use of natural resources and proper management of the building during its lifetime.

\section{References}

Barbut, M. (2006). Sustainable Building and Consumption Initiative (SBCI). [Online] Available at: http://www.unep.fr/shared/about/sbci_speech.pdf

[Accessed 2211 2012].

Boyle, C. (2005). Sustainable buildings. Proceedings of the Institution of civil engineer. [Online]

Available at: http://www.homepages.ucl.ac.uk/ ucessjb/S3\%20Reading/boyle\%202005.pdf [Accessed 112 2012].

CSO, C. S. O., (2011). Housing census 2011. [Online]

Available at: http://www.gov.mu/portal/goc/cso/ei915/esi2011.pdf

[Accessed 2211 2012].

CWA, C. W. A., (2013). Save Water Tips. [Online]

Available at: http://cwa.gov.mu/English/CWA-Services/Pages/Save-Water-Tips.aspx [Accessed 132 2013].

IIEC, I. I. f. E. C., (2012). Eco-housing Assessment Criteria Retrofit Construction. [Online] Available at: http://portal.mcgm.gov.in/irj/portalapps/com.mcgm.ecohousing/docs/Eco_housing_Retrofit_ Projects.pdf

[Accessed 112 2012].

IndexMundi, (2013). Mauritius Central bank discount rate. [Online]

Available at: http://www.indexmundi.com/mauritius/central_bank_discount_rate.html [Accessed 0602 2013].

Mauritius Research Council, M., (2012). A Coordinated Research Perspective on Sustainable Buildings in Mauritius, s.l.: Mauritius Research Council. 
MRI Water Solutions, (2013). HDPE Pipe vs. PVC Pipe. [Online]

Available at: http://image11.photobiz.com/3907/20110424125559_113181.pdf

[Accessed 143 2013].

Stockbroking, L. A., (2012). The Mauritian Economy: 2012 Outlook. [Online]

Available at: http://www.axys-group.com/photo/News/Pdf/doc24.pdf

[Accessed 2211 2012].

UNEP, S., (2011). Sustainable Buildings. [Online]

Available at: http://www.unep.org/sbci/pdfs/SBCI_infonote_220211_web.pdf

[Accessed 2001 2013].

USEPA, U. E. P. A., (2012). Why Build Green?. [Online]

Available at: http://www.epa.gov/greenbuilding/pubs/whybuild.htm

[Accessed 2211 2012].

\section{Copyright Disclaimer}

Copyright for this article is retained by the author(s), with first publication rights granted to the journal.

This is an open-access article distributed under the terms and conditions of the Creative Commons Attribution license (http://creativecommons.org/licenses/by/3.0/). 